\title{
POLITIKA
}

\section{POLITINIO ATSTOVAVIMO GALIMYBIŲ PLĖTRA? LIETUVOS PARLAMENTARŲ POŽIŪRIO İ MOTERŲ KVOTAS ANALIZĖ}

Prof. Irmina MatonytE $\dot{E}^{1}$

ISM Vadybos ir ekonomikos universitetas

ISM University of Management and Economics, professor

E. Ožeškienès g. 18, LT-44254 Kaunas

El.paštasirmina.matonyte@ismi.lt

OKsana Mejeré

Vytauto Didžiojo universitetas, doktorantè

Vytautas Magnus University, PhD candidate

Donelaičio g. 58, LT-44248 Kaunas

El.paštaso.mejere@cr.su.lt

„Politikoje atsiranda galimybių moterims, bet jos dalinès, lokališkos; jos tẻra esamos valdžios nuolaidos, bet ne naujų vertybių įtvirtinimas.“ (L. Irigaray, 1985)

\section{Santrauka}

Straipsnyje, paremtame pusiau struktūruotu interviu su Lietuvos Seimo nariais medžiaga, analizuojama tiek bendrojo diskurso, susijusio su moteru atstovavimo politikoje stiprinimu, kaita, tiek Seimo nariu konkrečiai reiškiamo požiūrio ị lyčiu kvotas ypatumai, pristatant formalaus

1 Už pagalbą atliekant tyrimą ir rengiant publikaciją autorès dèkoja Ernestai Butkuvienei ir Aurelijai Novelskaitei. 
struktūrinio lyčiu atstovavimo sovietiniame režime patirtis ir santykinai nykstančio moteru atstovavimo požymius demokratinejje politikoje. Atskleidžiama, kad nei priklausymas politinei partijai, nei "plitimo“ (angl. contagion) efektas, nei ekonominès ir socialinès pletros veiksniai trumpuoju laikotarpiu nedaro pastebimo poveikio lyčiu lygybès diskurso kaitai ir nestimuliuoja teigiamų nuostatu lyčių kvotu ar moteru atstovavimo politinèje arenoje didinimo atžvilgiu.

Reikšminiai žodžiai: politinis atstovavimas; kvotos; parlamentinis elitas; moterys.

\section{Ivadas}

Lietuvoje komunistinès santvarkos žlugimas sudarè palankias sąlygas plètotis valstybiniam suverenitetui, savarankiškai formuojant viešąą politiką ir diegiant demokratines politines vertybes. Stojimas ị Europos Sąungą (ES) paskatino rūpintis demokratijos kokybe. Viena iš tokių naujai atgimusių politinio diskurso sričių tapo lyčių lygybės politika „pagrindinè teisé, bendra ES vertybė ir būtina sąlyga ES ekonomikos augimo, užimtumo ir socialinès sanglaudos tikslams pasiekti“2. Lietuvos Respublikos Seimas 1998 m. patvirtino Moterų ir vyrų lygių galimybių ịstatymą, $1999 \mathrm{~m}$. ịsteigė Moterų ir vyrų lygių galimybių kontrolieriaus tarnybą; pritarẻ Valstybinei moterų ir vyrų lygių galimybių programai.

Pažymètina, kad nuo pat demokratijos kūrimo pradžios Lietuvos politinès partijos formavosi pagarbos lyčių lygybei linkme: praktiškai visos stengèsi atsižvelgti ị moterų rinkèjų poreikius, kai kurios net savo viduje ịkūrẻ moterų skyrius, o socialdemokratų ir Moterų (1998 m. Moteru partija transformavosi į centristinę Naujosios demokratijos partiją, kuri $2001 \mathrm{~m}$. susijungè su Lietuvos valstiečių liaudininkų sąunga) partijos

2 A Roadmap for equality between women and men 2006-2010, SEC(2006) 275, Brussels, 01.3.2006 COM(2006), 92 final. Prieiga per internetą: <http://eur-lex.europa. eu/LexUriServ/site/en/com/2006/com2006_0092en01.pdf> [žiūrèta 2010-11-04]. 
savo viduje ėmé taikyti lyčių kvotas ${ }^{3}$. Vis dèlto nepaisant, atrodo, palankaus politinio elito požiūrio ị lyčių lygybès principą, $2001 \mathrm{~m}$. parlamentarès Birutès Vèsaitès (socialdemokratès) pasiūlyta pataisa rinkimuose $i$ savivaldybių tarybas taikyti lyčių kvotas visų partijų sąrašuose nesulaukè pakankamo kitų partijos narių palaikymo ir buvo atmesta ${ }^{4}$. Toks pat likimas ištiko ir Seimo moterų, plètojančių feministines pažiūras, bandymus institucionalizuoti pariteto (angl. zipping) principą rinkimuose i Europos Parlamentą $2004 \mathrm{~m}$. Prie šių klausimų Seime vẻliau nebuvo grižta.

Socialdemokratès Sigitos Burbienès nuomone, 2002 metais „toks pasipriešinimas pasiūlytam projektui tikriausiai reiške konkurencijos baimę ${ }^{\text {“5 }}$. Tačiau buvo reiškiami ir visiškai priešingi argumentai: abejonès dèl kvotų priemonès atitikties Konstitucijai ir liberali opozicija apskritai bet kokiems „dirbtiniams principams“. Panašios pozicijos kvotų atžvilgiu laikosi ir 2009 m. birželị išrinkta Lietuvos Prezidentė - pirmoji moteris, užimanti ši postą, Dalia Grybauskaitè, kuri 2010 m. vasarą sukritikavo tuo metu viešojoje erdvèje vèl èmusią sklandyti lyčių kvotų idèją. Prezidentè, teigdama, kad lyčių kvotų įtvirtinimas sumenkintų moterų profesinị kompetentingumą, pabrèžè, jog pati nenorètų būti kvotų moterims dalimi ${ }^{6}$.

Taigi lyčių kvotų institucionalizavimo vertinimas pasižymi politinių interpretacijų ívairove. Nagrinẻjant lyčių aspektus Lietuvos politikoje galima išskirti šias binarines opozicijas: ES versus nacionalinè valstybinè pozicija, formalioji politika versus realūs socialiniai veiksmai, politiškai

3 Matonyte, I., Krupavičius, A. Women in Lithuanian Politics: From Nomenklatura Selection to Representation. Women's Access to Political Power in Post-Communist Europe. Eds. R. E. Matland, K. A. Montgomery. Oxford: Oxford University press, 2003, p. 81-104.

4 Bieliavska, J. Seimas nepritarė lyčių kvotoms rinkimuose. Prieiga per internetą: $<$ http:// www.elta.1t/rinkimai2002/index.php?ItemId=5176> [žiūrèta 2010-11-05].

5 Ten pat.

6 Tačiau 2004 m., tuo metu žinoma kaip finansų ministrè, Dalia Grybauskaitė tapo Lietuvos atstove Europos Komisijoje, kurios sudètis grindžiama „kvotų šaliai“ principu ir kaip atsakas i senujų ES valstybių narių paskatinimą naujosioms šalims deleguoti į Europos komisarus būtent moteris politikes. 
skelbiamos vertybės versus kasdieninė gyvenimiškoji praktika, moterys versus vyrai. Galima teigti, kad pastarosiosios dichotomijos reikšmè yra itin svarbi, t. y. fizinis moterų buvimas politineje arenoje tarnauja kaip lakmuso popierèlis, pažymintis valstybès (ne)gebẻjimą išplèsti moterų atstovavimo ir dalyvavimo politikoje ribas. Kita vertus, siekiant atskleisti daugialypius kasdienybès požiūrius ir juos apibrèžiančius galios santykius, yra būtinos intersekcionalumo įžvalgos: žmogaus priklausymas keletui (aptariamu atveju - žemesniųjų) socialinių pozicijų vienu metu, akumuliuojant ir ịtvirtinant (aptariamu atveju - pavaldumo) santykị su galios centrais ${ }^{7}$.

Anot Joanos Acker, „visose organizacijose galima aptikti nelygybės santvarkų "8. Seimas, būdamas viena ryškiausių ir galingiausių politinių institucijų, ne tik atstovauja visuomenès interesams ir lūkesčiams, bet ir keičia juos. Straipsnio tikslas - atlikus Lietuvos parlamentarų požiūrio ị lyčių kvotas analizę, rekonstruoti "lyčių nelygybės režimą" Seime. Studijoje analizuojami interviu su dviejų kadencijų (1996-2000 m.; 2000-2004 m.) Lietuvos Seimo nariais ir atskleidžiama praktika, procesai, veiksmai ir reikšmès, palaikančios lyčių nelygybę.

\section{Lyčių kvotos: empiriniai ir praktiniai aspektai}

Aktyvaus moterų dalyvavimo politikoje reikšmė siejama su politinio atstovavimo plètra ir galimybe pažvelgti i problemas naujai, $\mathfrak{i}$ formaliosios politikos sritị ịtraukiant naujų problemų matymo būdų ir sprendimų priemimo modelių. ${ }^{9}$ Politinis atstovavimas apibrèžiamas kaip visuomenès narių ir grupių dalyvavimas ir aktyvi veikla formaliosios politi-

Phoenix, A., Pattynama, P. Editorial: Intersectionality. European Journal of Women's Studies. 2006, Nr. 13, p. 189.

8 Acker, J. Inequality Regimes: Gender, Class, and Race in Organizations. Gender \& Society. 2006, Nr. 20, p. 443.

9 Footitt, H. Women, Europe and the New Languages of Politics. London, New York: Continuum, 2002; Sapiro, V. Gender, Social Capital, and Politics. Gender and Social Capital. Eds. B. O’Neill, E. Gidengil. Routledge, 2006. 
kos institucijose $\mathrm{e}^{10}$. Siaurąja prasme grupès politinis atstovavimas reiškia konkrečios grupès interesų atstovavimą; plačiąja prasme politinis atstovavimas apima ịvairių grupių interesų, požiūrių ir lūkesčių pripažinimą politinès institucijos lygmeniu ${ }^{11}$.

Pagrindiniai pokyčiai politinių sistemų srityje pasaulio mastu siejami su padidejusiomis moteru politinio atstovavimo galimybèmis ${ }^{12}$. Didžiąa dalimi išaugusios galimybès siejamos su lyčių kvotų sistemos taikymu vykdant kandidatų i politinius postus atranką ir organizuojant rinkimus. Šių idèjų ištakos glūdi 1995 m. Jungtinių Tautų ketvirtosios Moterų konferencijos metu pasirašytoje Pekino deklaracijoje ir Veiksmų plane, kuriam visais balsais pritare 189 šalys, ragindamos vyriausybes imtis efektyvių priemonių, užtikrinančių galimybes moterims siekti ir lygiaverčiai dalyvauti sprendimų prièmimo struktūrose, plètoti moterų kompetencijas dalyvauti priimant sprendimus ir siekti lyderystès. Pažymėtina, kad Lietuva irgi yra įsipareigojusi vykdyti ši Veiksmų planą.

Iki $1980 \mathrm{~m}$. lyčių kvotos buvo priimtos tik dešimtyje valstybių, o 1990-aisiais šalių, taikančių kvotas politinių partijų sistemose, skaičius išaugo penkis kartus. Aktyviausiai lyčių kvotos buvo diegiamos per paskutiniuosius penkiolika-dvidešimt metų ${ }^{13}$. Remiantis Pasaulinès kvotų moterims duomenų bazès ${ }^{14}$ (angl. Global Database of Quotas for Women) duomenimis, per pastaruosius 20 metų ivvairių tipų kvotų moterims klausimas buvo svarstomas net 103 šalyse. Pabrèžtina, kad lyčių kvotos buvo ivedamos šalyse, besiskiriančiose ekonominiu išsivystymo lygiu, politine kultūra ir sociokultūriniais gyvenimo standartais ${ }^{15}$.

${ }^{10}$ Pitkin, H.F. The Concept of Representation. Los Angeles: University of California Press, 1972.

${ }^{11}$ Lovenduski, J. Feminizing Politics. Polity Press, 2005.

${ }^{12}$ Krook, M.L. Quota Laws for Women in Politics: A New Type of State Feminism? European Consortium for Political Research Workshop (manuscript). Granada, 2005, p. 3.

13 Ten pat, p. 4.

${ }^{14}$ Global Database of Quotas for Women. Prieiga per internetą: <http://www.quotaproject. org/case_studies.cfm> [žiūrèta 2010-12-03].

${ }^{15}$ Krook, M.L. Quota Laws for Women in Politics: ANew Type of State Feminism? European Consortium for Political Research Workshop (manuscript). Granada, 2005, p. 32-34. 
Lyčių kvotų taikymas paskatino mokslinių tyrimų, skirtų kvotų sistemos ịvedimo, ịtvirtinimo ir poveikio analizei, plètrą. Kaip teigia Drudè Dahlerup, nepaisant kontraversiškų nuostatų kvotų atžvilgiu, tai yra priemoné, suteikianti galimybę skatinti aktyvesnį moterų dalyvavimą formaliojoje politikoje $\mathrm{e}^{16}$. D. Dahlerup nagrineja du kvotų modelius: greitojo kelio (angl. fast track) ir nuoseklaus kelio (angl. incremental track). Pastarasis modelis grindžiamas nuostata, kad siekiant sumažinti moterų ir vyrų turimų politinių išteklių skirtumus, būtina skatinti laipsniškus pokyčius, lemiančius nuoseklų lyčių kvotų ịvedimą. Greitojo kelio strategija remiasi nuostata, kad išstūmimas ir diskriminacija yra esminiai požymiai, kurių atpažinimas ir suvokimas turi skatinti imtis ryžtingų veiksmų ieškant problemos sprendimo. Taigi, šis kvotų modelis akcentuoja poreikį veikti radikaliai ${ }^{17}$.

D. Dahlerup i̇vardija šiuos kvotas palaikančius argumentus: kvotos užtikrinta abiejų lyčių lygias galimybes dalyvauti priimant sprendimus; jos skatina politines partijas įtraukti daugiau moterų ị rinkimų sąrašus; moterys, sudarydamos pusę pasaulio (šalies) populiacijos, turi demokratiniais principais pagrịstą teisę sudaryti pusę visų narių parlamentuose; kvotos suteikia galimybę moterims reikštis kaip grupei; kadangi dažniausiai moterų (kaip socialinès grupès) gebejjimai (kvalifikacijos) vertinami prasčiau nei vyrų, kvotos nèra vyrų diskriminacijos ženklas, o tik atsakas ị moterų diskriminaciją; kvotų ịvedimas sukelia tik laikiną konfliktą; kvotos moterims ,amortizuoja“ bendrai pasireiškianti principą, kad tiek vyrai, tiek moterys yra linkę balsuoti už vyrus; kvotos pagerina partijų įvaizdį $i^{18}$.

Pasaulinejje kvotų moterims duomenų bazèje ${ }^{19}$ pateikiami argumentai, prieštaraujantys kvotų reikalingumui: kvotos, suteikdamos moterims pranašumą prieš vyrus, pažeidžia lyčių lygių galimybių principus; kvotos

${ }^{16}$ Women, Quotas and Politics. Ed. D. Dahlerup. London, New York: Routledge, 2006.

${ }_{17}$ Ten pat, p. 8

18 Ten pat.

${ }^{19}$ Global Database of Quotas for Women. Prieiga per internetą: $<$ http://www.quotaproject. org/case_studies.cfm> [žiūrèta 2010-12-03]. 
yra nedemokratiškas reiškinys, nes rinkėjai patys turètų nuspręsti, kas bus išrinktas; kvotos, prioritetą teikdamos lyčiai, o ne politiko kvalifikacijai, aukštesnę kvalifikaciją turinčius kandidatus gali palikti nuošalyje; daugelis moterų nesutinka būti renkamos vien dèl to, kad yra moterys; kvotų ịvedimas sukelia papildomų konfliktų, prieštaravimų partinių organizacijų viduje.

Mokslinèje literatūroje pateikiama daugybė kvotų klasifikavimo tipologijų, išskiriant tokius kvotų analizei reikšmingus požymius kaip kvotu modelis (neutralios lyčių kvotos (angl. gender-neutral) ar specifinès lyčių kvotos (angl. gender-specific), kvoty taikymo ipareigojimo lygmuo (nacionaliniais įstatymais ịtvirtintos ar savanoriškai taikomos, numatytos atskirų politinių partijų statutuose) bei lyčiu kvotų taikymo sritis (kvotos taikomos: a) atrenkant potencialius kandidatus į rinkimų sąrašus; b) sudarant partijos rinkimų sąrašus; c) jau išrinktiems partijos atstovams) ${ }^{20}$.

Iš esmès galima išskirti tris pagrindinius lyčių kvotų tipus: moterims rezervuotos vietos; vidines partiju kvotos; politinio atstovavimo (kai kur ir plačiau - viešosios, ne privačios veiklos sričių) kvotos, ịtvirtintos įstatymais. Pirmojo tipo (rezervuotos vietos) kategorija nèra reikšminga kandidatų iškèlimo procese, o tik garantuoja specialias sąlygas įsitraukimo ị politiką procese ${ }^{21}$. Trečiojo tipo (įstatymais įtvirtinto pariteto) kategorija yra pati plačiausia, tačiau pabréžtina, kad pariteto principas ir lyčių kvotos yra ilgalaikio proceso, susijusio su politinio atstovavimo trūkumais, rezultatas. Anot Berengerès Marques-Pereira ir Birtès Siim, paritetas ir kvotos - tai dvi strategijos, galinčios padèti išspręsti nepakankamo moterų dalyvavimo politikoje problemą ir taip sumažinti politinio atstovavimo demokratiškumo deficitą ${ }^{22}$. Viena iš tokių šalių, praktiškai taikančių

${ }^{20}$ Dahlerup, D., Freidenvall, E. et al. Electoral Gender Quota Systems and their Implementation in Europe. Brussels, 2008. Prieiga per interneta: $<$ http://www.europarl. europa.eu/document/activities/cont/200903/20090310ATT51390/20090310ATT51390 EN.pdf> [žiūrèta 2010-12-22].

${ }^{21}$ Women, Quotas and Politics. Ed. D. Dahlerup. London, New York: Routledge, 2006.

${ }^{22}$ Marques-Pereira, B., Siim, B. Represenation, agency and empowerment. Contested concepts in gender and social politics. Eds. B. Hobson, J. Lewis, B. Siim. Massachusetts: Edward Elgar Publishing, 2004. 
abi minètas strategijas, yra Prancūzija, žinoma kaip pirmoji ES valstybė, ivvedusi ne tik kvotų sistemą, bet ir 1999 m. konstituciškai įteisinusi privalomą lyčių pariteto principą politinèje atrankoje $\mathrm{e}^{23}$.

Daugelyje ES šalių kvotos yra taikomos politinèse partijose sudarant rinkimų kandidatų sąrašus (žr. 1 lentelę).

1 lentelé. Kvotų pobūdis ir moterų atstovavimas ES šalių nacionaliniuose parlamentuose

\begin{tabular}{|c|c|c|c|}
\hline \multirow[t]{2}{*}{ ES šalis ${ }^{1}$} & \multirow[t]{2}{*}{ Kvotų pobūdis } & \multicolumn{2}{|c|}{$\begin{array}{c}\text { Moterų skaičius } \\
\text { nacionaliniame } \\
\text { parlamente po } \\
\text { pastarųjų rinkimų }\end{array}$} \\
\hline & & $\mathbf{N}$ & $\%$ \\
\hline Austrija & Politinių partijų kvotos kandidatams & 59 iš 183 & $32,2 \%$ \\
\hline Belgija & $\begin{array}{l}\text { Kvotų reguliavimas rinkimų istatymu. } \\
\text { Konstituciškai arba kitais įstatymais priimtos } \\
\text { kvotos, kvotos regioniniame lygmenyje. Politinių } \\
\text { partijų kvotos kandidatams }\end{array}$ & 55 iš 150 & $36,7 \%$ \\
\hline Kipras & Politinių partijų kvotos kandidatams & 8 iš 56 & $14,3 \%$ \\
\hline Čekija & Politinių partijų kvotos kandidatams & 31 iš 200 & $15,5 \%$ \\
\hline Danija & $\begin{array}{l}\text { Kvotos veikè anksčiau arba kvotų îvedimas } \\
\text { svarstomas }\end{array}$ & 67 iš 179 & $37,4 \%$ \\
\hline Prancūzija & $\begin{array}{l}\text { Kvotų reguliavimas rinkimų ịstatymu. } \\
\text { Konstituciškai arba kitais ịstatymais priimtos } \\
\text { kvotos, kvotos regioniniame lygmenyje. Politinių } \\
\text { partijų kvotos kandidatams }\end{array}$ & 107 iš 577 & $18,5 \%$ \\
\hline Vokietija & Politinių partijų kvotos kandidatams & 195 iš 614 & $31,8 \%$ \\
\hline Graikija & $\begin{array}{l}\text { Konstituciškai arba kitais ịstatymais priimtos } \\
\text { kvotos, kvotos regioniniame lygmenyje. Politinių } \\
\text { partijų kvotos kandidatams }\end{array}$ & 48 iš 300 & $16 \%$ \\
\hline Vengrija & Politinių partijų kvotos kandidatams & 41 iš 386 & $10,6 \%$ \\
\hline
\end{tabular}

${ }^{23}$ Ilonszki, G. Women in politics: The European Union and Hungary. Changing Roles: Report on the Situation of Women and Men in Hungary. Eds. I. Nagy, M. Pongracz, I. G. Toth. Budapest: Tarki Social Research Institute, 2006, p. 59. Prieiga per internetą: $<$ http://www.tarki.hu/en/publications/CGR/> [žiūrèta 201010 24]. 


\begin{tabular}{|c|c|c|c|}
\hline Airija & Politinių partijų kvotos kandidatams & 22 iš 166 & $13,3 \%$ \\
\hline Italija & Politinių partijų kvotos kandidatams & 109 iš 630 & $17,3 \%$ \\
\hline Lietuva & Politinių partijų kvotos kandidatams & 29 iš 141 & $20,6 \%$ \\
\hline Malta & Politinių partijų kvotos kandidatams & 6 iš 65 & $9,2 \%$ \\
\hline Nyderlandai & Politinių partijų kvotos kandidatams & 55 iš 150 & $36,7 \%$ \\
\hline Lenkija & Politinių partijų kvotos kandidatams & 94 iš 460 & $20,4 \%$ \\
\hline Portugalija & $\begin{array}{l}\text { Kvotų reguliavimas rinkimų ịstatymu. } \\
\text { Konstituciškai arba kitais ịstatymais priimtos } \\
\text { kvotos, kvotos regioniniame lygmenyje. Politinių } \\
\text { partijų kvotos kandidatams }\end{array}$ & 49 iš 230 & $21,3 \%$ \\
\hline Rumunija & Politinių partijų kvotos kandidatams & 38 iš 332 & $11,5 \%$ \\
\hline Slovakija & Politinių partijų kvotos kandidatams & 24 iš 150 & $16 \%$ \\
\hline Slovėnija & $\begin{array}{l}\text { Kvotų reguliavimas rinkimų istatymu. } \\
\text { Konstituciškai arba kitais ịstatymais priimtos } \\
\text { kvotos, kvotos regioniniame lygmenyje. Politinių } \\
\text { partijų kvotos kandidatams }\end{array}$ & 12 iš 90 & $13,3 \%$ \\
\hline Ispanija & $\begin{array}{l}\text { Kvotų reguliavimas rinkimų ịstatymu. } \\
\text { Konstituciškai arba kitais ịstatymais priimtos } \\
\text { kvotos, kvotos regioniniame lygmenyje. Politinių } \\
\text { partijų kvotos kandidatams }\end{array}$ & 127 iš 350 & $36,3 \%$ \\
\hline Švedija & Politinių partijų kvotos kandidatams & 165 iš 349 & $47,3 \%$ \\
\hline $\begin{array}{l}\text { Didžioji } \\
\text { Britanija }\end{array}$ & Politinių partijų kvotos kandidatams & 128 iš 646 & $19,9 \%$ \\
\hline
\end{tabular}

Šaltinis: Global Database of Quotas for Women, 200907 15. Prieiga per internetą: <http://www.quotaproject.org/case_studies.cfm $>$.

40-yje pasaulio šalių kvotos yra ịteisintos konstituciškai, dar 50-yje šalių moterų kvotos priimtos kaip partijų strateginè norma. Efektyviausiai kvotų sistema veikia Šiaurès Europos šalyse, kuriose partijos, sudarydamos rinkimuose dalyvausiančių kandidatų sąrašus, taiko specifines lyčių kvotas (gender-specific quotas), užtikrinančias moterims galimybę sudaryti ne mažiau kaip 40 proc. visų kandidatų ${ }^{24}$.

Taigi akademinès ir demokratinès politinès nuostatos yra vienaprasmiškos: lyčių kvotos gali veikti kaip reikšminga priemonè, mažinanti ly-

${ }^{24}$ Women's Access to Political Power in Post-Communist Europe. Eds. R. E. Matland, K. A. Montgomery. Oxford University Press, 2003, p. 32. 
čių disbalansą politikoje $\mathrm{e}^{25}$. Svarstant moterų politinio dalyvavimo plètros galimybes dėmesys dažnai kreipiamas ị Skandinavijos šalis, kuriose moterų politinis atstovavimas didžiausias visame pasaulyje. Tačiau svarbu prisiminti, kad šiose šalyse lyčių kvotos rinkimų politikoje buvo pradètos taikyti 1970 ir 1980 metais $^{26}$. Dabartinès situacijos, kai moterys Šiaurès šalių parlamentuose sudaro virš 30 proc. narių, buvo siekiama apie 60 metų $^{27}$, todèl šios patirties negalima laikyti šiuolaikiniu modeliu. Kita vertus, kai kurios Afrikos šalys, plačiai taikydamos lyčių kvotas ir mobilizuodamos moterų elektoratą, aukštą moterų dalyvavimo politikoje lygi pasiekè per santykinai trumpą laiką ${ }^{28}$. Taigi, kaip teigia D. Dahlerup, rinkimų kvotų ịvedimas išreiškia moterų politinį sąmoningumą bei nekantrumą ir yra veiksminga priemonė didinti moterų politinị atstovavimą ${ }^{29}$.

Tiriant lyčių kvotų taikymo pokomunistinèse šalyse praktiką dažnai pamirštama šių valstybių sovietmečio patirtis. Kai kurios mokslininkès mano, kad komunistinė patirtis, kai lyčių kvotos buvo naudojamos siekiant instituciškai užtikrinti lyčių lygybę politinejje arenoje, pokomunistinėms valstybėms suteikia tam tikrą santykinị pranašumą formuojant politinès kultūros tradiciją lyčių lygybès srityje ${ }^{30}$. Tačiau kiti autoriai tvirtina, kad sovietinis moterų dalyvavimas politikoje buvo tik deklaruo-

${ }^{25}$ Norris, P., Inglehart, R. Cultural Barriers to Women's Leadership: A Worldwide Comparison. International Political Science Association World Congress, Special Session 16 'Social Cleavages and Elections' (manuscript). Quebec City, 2000; Holli, A. M., Luhtakallio, E., Raevaara, E. The Implementation of Gender Quotas in Local Government in Finland. European Consortium for Political Research Workshop (manuscript). Edinburgh, 2003.

${ }^{26}$ Gray, T. Electoral Gender Quotas: Lessons from Argentina and Chile. Bulletin of Latin American Research. 2003, vol. 22, p. 52-78.

27 The Implementation of Quotas: African Experiences. Quota Report Series. Ed. by J. Ballington. 2004. Prieiga per internetą: $<$ http://www.idea.int/publications/quotas_africa/ index.cfm> [žiūrèta 2010-10-23].

${ }^{28}$ Ten pat.

${ }^{29}$ Dahlerup, D. Comparative Studies of Electoral Gender Quotas. The Implementation of Quotas: Latin American Experiences Workshop. Peru, 2003.

${ }^{30}$ Antić, M.G., Ilonszki, G. Women in Parliamentary Politics: Hungarian and Slovene Cases Compared. Ljubljana: Peace Institute, 2003. 
jamos ir dekoracinès politinės ideologijos reiškinys ${ }^{31}$. Nepaisant to, kad moterų atstovavimas Lietuvos Socialistinès Respublikos Aukščiausiojoje Taryboje nuolatos augo (nuo 22 proc. iki 36 proc.) ${ }^{32}$, tikroji valdžia buvo sukoncentruota komunistinès partijos aparate ir ministrų kabinetuose, kuriuose moterys sudarè nykstančią mažumą ${ }^{33}$. Taigi, Sovietų Sąungoje taikytas lyčių kvotas galima laikyti nacionalinio-komunistinio patriarchato veidmainystès apraiška, nes iš moterų ir toliau buvo tikimasi paklusnumo ir nuolankumo, tikrosios galios išteklius koncentruojant vyrų rankose $^{34}$. Be to, sovietmečiu moteru politinis atstovavimas labiau priminè prievolę, primestą patriarchalinès viršūnès, norinčios simbolizuoti lyčių lygybès pasiekimus ir užslèpti politinị atvirų socialinių-politinių nuomonių ribojimą ${ }^{35}$.

Po Sovietų Sąungos žlugimo pokomunistinèse Europos valstybèse prasidejus demokratizacijos procesams buvo stebimos ryškios parlamentų „maskulinizavimo“ tendencijos. Didžiausias kiekybinis pokytis buvo stebimas Rumunijoje, kur po 1990 m. rinkimų moterų skaičius parlamente sumažejo nuo 33 iki 3,5 proc. ${ }^{36}$ Bulgarijoje moterų parlamente sumažèjo nuo 21 iki 8,5 proc., Vengrijoje - nuo 21 iki 7 proc., Čekoslovakijoje - nuo 29,5 iki 6 proc. ${ }^{37}$ Be to, ypač pirmaisiais demokratizaci-

${ }^{31}$ Matonytė, I. Women MPs in the Lithuanian Seimas 2006: still hostages of the masculine parliamentary tradition and organizational culture? Studia polityczne. 2007, Nr. 19, p. $25-52$.

${ }^{32}$ Matonytė, I., Krupavičius, A. Women in Lithuanian Politics: from Nomenklatura Selection to Representation. Women's Access to Political Power in Post-Communist Europe. Eds. R. E. Matland, K. A. Montgomery. Oxford: Oxford University press, 2003, p. 83.

${ }^{33}$ Moterys ir rinkimai. Vilnius: MIC, 1998, p. 10.

${ }^{34}$ Roman, D. Gendering Eastern Europe: Pre-feminism, Prejudice, and East-West Dialogues in Post-communist Romania. Women's Studies International Forum. 2001, vol. 24, issue 1, p. 58.

35 Sloat, A., Galligan, Y. Understanding women's political engagement in the new democracies of Central and Eastern Europe. Workshop „,Gender and Transition in Europe“, PSA (manuscript). Leicester, 2003, p. 8.

${ }^{36}$ Watson, P. The Rise of Masculinism in Eastern Europe. New Left Review. 1993, vol. a.

${ }^{37}$ Watson, P. Politics, policy and identity: EU Eastern enlargement and East/West differences. Journal of European Public Policy. 2003, No 7, p. 375. 
jos metais, buvo stebimas stiprus politinis pasipriešinimas kvotų ar bet kokių kitų priemonių, primenančių sovietinę patirtį, taikymui rinkimų politikoje $\mathrm{e}^{38}$. Lyčių kvotu ịtvirtinimas nacionaliniais įstatymais arba savanoriškas ịtraukimas ị politinès partijos ịstatus buvo lydimas pastangų atsiriboti nuo sovietinès patirties. Kaip pažymi Richardas E. Matlandas, pokomunistinių parlamentų nariai, palaikantys ir vykdantys lobizmą už lyčių kvotų ịtvirtinimą, pabrěždavo, kad palaiko socialdemokratinio tipo kvotas kaip Švedijos ir Norvegijos partijose, o ne bando grąžinti sovietmečio praktiką ${ }^{39}$.

Dabartiniu metu įvairaus pobūdžio kvotos yra taikomos visose posovietinèse valstybėse (išskyrus Bulgariją). Pavyzdžiui, Moldovoje, Bosnijoje ir Hercegovinoje lyčių kvotų taikymas yra įtvirtintas visuose lygiuose (konstitucijos, nacionalinès teisès ir politinių partijų); Serbijoje, Slovėnijoje, Rumunijoje, nuo 2010 m. gruodžio - Lenkijoje ${ }^{40}$ moterų atstovavimas partijų rinkimų sąrašuose yra reguliuojamas nacionalinès teisès; Čekijoje, Kroatijoje, Vengrijoje, Lietuvoje lyčių kvotos yra savanoriškai taikomos tik kai kuriose partijose. Lyčių kvotos yra ir Rusijos Dagestano regione ${ }^{41}$. Kirgizijoje kvotas praktikuoja tik Moterų demokratinè partija. Armėnijoje yra priimtas valstybinis įstatymas, reguliuojantis

${ }^{38}$ Renc-Roe, J. The Representation of Women in the Political Decision-Making Process in Poland: Existing Problems and Advocated Solutions. ECPR Joint Session: , Changing Constitutions, Building Institutions and (Re) defining Gender Relations “ (manuscript). Edinburgh, 2003; Sloat, A., Galligan, Y. Understanding women's political engagement in the new democracies of Central and Eastern Europe. Workshop „Gender and Transition in Europe “, PSA (manuscript). Leicester, 2003.

${ }^{39}$ Matland, R. E. The Representation of Women in Political Parties in Central and Eastern Europe. The Political Representation of Social Interests in Central and Eastern Europe. Workshop Section 2. 2004, p. 15.

${ }^{40}$ Nuo 2010 m. gruodžio mèn. Lenkijoje ịvestos lyčių kvotos rinkimams ne tik į Seimą, bet ir i Europos Parlamentą ir savivaldybes. Partijų kandidatų sąrašuose 35 proc. vietų skiriama moterims ir mažiausiai tiek pat - vyrams. Prieiga per internetą: <http:// www.lrytas.1t/-12925722661292157116-lenkijos-partij\%C5\%B3-rinkiminiuoses\%C4\%85ra\%C5\%A1uose-prival\%C4\%97s-b\%C5\%ABti-35-proc-moter\%C5\%B3.htm> [žiūrèta 2011-01-03].

${ }^{41}$ Golosov, G.V. Political parties, electoral systems and women's representation in the regional legislative assemblies of Russia, 1995-1998. Party Politics. 2001, Nr. 7, p. 65. 
kvotas partijų rinkimų sąrašuose (ir kai kurios partijos šias kvotas taiko), o Uzbekistane, kuriame taip pat priimtas kvotas reglamentuojantis nacionalinis įstatymas, partijų lygmeniu lyčių kvotos nèra taikomos.

Lyčių kvotų taikymo šiuolaikinèse pokomunistinèse valstybèse apžvalga leidžia tvirtinti, kad „pokomunistinis pasipriešinimas lyčių kvotų ívedimui kaip sovietinio palikimo sugrąžinimui“42 yra laikinas procesas. Tikètina, kad viena iš mažejjančio kvotų atsisakymo priežasčių yra kartų kaita: kuo jaunesni politikai, tuo mažiau išgyventos (neigiamos) sovietinès patirties jie turi ir tuo rečiau savo politinius argumentus sieja su sovietmečiu taikyta praktika. Kita vertus, pasaulio istorinių ir rinkimų duomenų statistinè analizė rodo, kad „kvotų taikymas stipriai koreliuoja su rinkimų teisès moterims suteikimo laiku

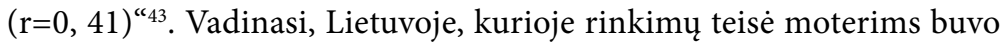
suteikta dar 1918 metais, lyčių kvotos galètų būti gana priimtinos ir plačiai taikomos. Vis dèlto iš istorijos žinome, kad iki sovietinės okupacijos lyčių kvotos buvo taikomos tik vienoje Lietuvos partijoje, kuri iš tiesų niekada nebuvo valdžioje. Abejonių dẻl minètos koreliacijos kelia ir kitų Europos valstybių istoriniai pavyzdžiai: nepaisant to, kad Prancūzijoje ir Belgijoje rinkimų teisè moterims buvo suteikta tik 1944 ir 1948 m., dabartiniu metu šiose valstybèse veikia pariteto sistema ir plačiai taikomos lyčių kvotos; Vokietijoje ir Didžiojoje Britanijoje lyčių kvotos naudojamos tik pavienių partijų lygmenyje, nors balsavimo teisę moterys igijo 1919 ir 1928 m. Taigi įžvalga, kad moterų dalyvavimo šalies politiniame gyvenime trukmè lemia specialiųjų priemonių, skirtų išlyginti lyčių disbalansą tarp politinio elito atstovų, ịvedimą neturètų būti suabsoliutinta. Vis dèlto galima pagrịstai teigti, kad gilios moterų politinio dalyvavimo tradicijos prisideda prie teigiamo požiū-

42 Sloat, A., Galligan, Y. Understanding women's political engagement in the new democracies of Central and Eastern Europe. Workshop „Gender and Transition in Europe “, PSA (manuscript). Leicester, 2003.

${ }^{43}$ Studlar, D.T., McAllister, I. Does a critical mass exist? A Comparative analysis of women's legislative representation since 1950. European Journal for Political Research. 2002, vol. 41, p. 247. 
rio formavimo ir palankumo lyčių kvotoms politiniuose diskursuose ir praktikoje $\mathrm{e}^{44}$, ir kad šiuolaikiniame pasaulyje viešoji nuomonè vis labiau pritaria egalitariniams principams ${ }^{45}$.

\section{Tyrimo metodologija}

Lyginamasis lyčių kvotų tyrimas turi apimti ịvairius politinio gyvenimo aspektus: viešąj diskursą, sprendimų prièmimo procesą, kvotų igyvendinimą ir kvotų pasekmes ${ }^{46}$. Straipsnyje pristatomo tyrimo išeities taškas yra diskurso lygmuo, o kognityvinès, emocinès ir normatyvinès parlamentar(i)ų (moterų ir vyrų) nuostatos lyčių kvotų atžvilgiu čia naudojamos kaip instrumentas, leidžiantis giliau pažvelgti i pagrindinių principų ir politinio atstovavimo (re)organizaciją pokomunistinèse demokratijose. Analizei naudojama dviejų empirinių tyrimų, kuriuose dalyvavo dviejų iš eilès Seimo kadencijų (1996-2000 m., 2000-2004 m.) parlamentarai, medžiaga.

Pirmasis tyrimas vyko 1999 m. rudeni, paimti pusiau struktūruoti interviu iš visų tuometinių parlamentinių partijų atstovų $\left(\mathrm{n}_{\text {moterys }}=9 ; \mathrm{n}_{\text {vyrai }}\right.$ =5). Respondentai atrinkti taip, kad būtų apklausta bent po vieną vyrą ir moterị iš pagrindinių parlamentinių partijų, pageidautinai - partijos lyderiai. Tyrime taip pat dalyvavo trys aktyvūs pilietinès visuomenès nariai (vienas vyras ir dvi moterys), susiję su atstovavimu moterų interesams (iš profesinès sąungos, žiniasklaidos ir visuomeninès organizacijos). Interviu metu buvo gvildenamos trys pagrindinès temos: a) svarstymai apie moterų organizacijų statusą ir veiklą sovietmečiu ir dabartinejje Lietuvoje; b) Moterų ir vyrų lygių galimybių istatymo, priimto 1998 m.,

${ }^{44}$ Dahlerup, D. Comparative Studies of Electoral Gender Quotas. The Implementation of Quotas: Latin American Experiences Workshop. Peru, 2003.

${ }^{45}$ Norris, P., Inglehart, R. Cultural Barriers to Women's Leadership: A Worldwide Comparison. International Political Science Association World Congress, Special Session 16 'Social Cleavages and Elections' (manuscript). Quebec City, 2000.

${ }^{46}$ Dahlerup, D. Comparative Studies of Electoral Gender Quotas. The Implementation of Quotas: Latin American Experiences Workshop. Peru, 2003, p. 1. 
vertinimas; c) moterų politinès karjeros pokomunistineje Lietuvoje suvokimas. Lyčių kvotų klausimas čia buvo kontekstualus.

Antrojo tyrimo metu, taikant struktūruoto interviu metodą, $2004 \mathrm{~m}$. pavasarį buvo apklausti 28 tuometinio Seimo nariai $\left(\mathrm{n}_{\text {moterys }}=14^{47} ; \mathrm{n}_{\text {vyrai }}\right.$ =14). Tokį imties dydị nulèmė $2000 \mathrm{~m}$. ị Seimą išrinktų moterų skaičius, kontrolinè vyrų respondentų grupe buvo sudaryta atsitiktinès atrankos būdu. Šiame tyrime pateikti klausimai apie Seimo narių politinius prioritetus, politinių institucijų vaidmenis ir kt. Atskirą bloką sudarè klausimai apie moterų dalyvavimą skirtinguose politikos formavimo lygiuose, lyčių lygybę viešajame gyvenime ir moterų dalyvavimo politikoje stiprinimą.

Šiame straipsnyje siekiama atskleisti Seimo narių nuostatas dèl moterų dalyvavimo ir atstovavimo valstybinėse, politiką formuojančiose institucijose, ypač dèl lyčių kvotų, taip pat analizuojamos lyčių diskurso variacijos dviejų Seimo kadencijų laikotarpiu. Diskursyvūs skirtumai aiškinami: a) diferencijuojant vyrų ir moterų požiūrius bei b) atsižvelgiant ị Seimo sudèties skirtumus atskirose kadencijose.

\section{Moterys pokomunistiniame Lietuvos Seime: dalyvavimas ir atstovavimas}

1990 m. kovo 11 d. atkūrus Lietuvos nepriklausomybę prasidejo demokratijos ir laisvosios rinkos principais pagrịstų reformų igyvendinimas. Žymūs pokyčiai buvo stebimi ir parlamento sudètyje (žr. 2 lentelę). Vis dèlto nuo pat Nepriklausomybès atkūrimo iki 2008 m. Seimo rinkimų Lietuvos parlamente moterys vidutiniškai sudarè apie septintadalị (14 proc.) visų narių. O moterims palankus politinės darbotvarkès transformavimas arba sprendimų priėmimo stiliaus pokytis, anot D. Dahlerup, galimas tik tuomet, kai politinèse struktūrose veikia ne mažiau kaip trečdalis moterų ${ }^{48}$.

\footnotetext{
${ }^{47}$ Tyrimo metu buvo apklaustos visos $2000 \mathrm{~m}$. i Seimą išrinktos moterys.

48 Women, Quotas and Politics. Ed. D. Dahlerup. London, New York: Routledge, 2006.
} 
2 lentele. Moterys Lietuvos Respublikos Seime

\begin{tabular}{ccc}
\hline \multirow{2}{*}{ METAI } & \multicolumn{2}{c}{ MOTERYS } \\
\cline { 2 - 3 } & $\mathbf{N}$ & $\%$ \\
\hline 1990 & $12^{*}$ & 9,0 \\
1992 & 10 & 7,1 \\
1996 & 23 & 16,8 \\
2000 & 15 & 10,6 \\
2004 & 31 & 22,0 \\
2008 & 26 & 18,4 \\
\hline
\end{tabular}

* Bendras Seimo narių skaičius - 141.

Pastaba. Duomenys pagal Seimo kadencijų pradžios situaciją.

Patys Seimo nariai gana pesimistiškai vertino moterų dalyvavimo politikoje pokyčius. Daugelis (tarp jų ir moterys) neįžvelgè jokios pridètinès vertès, kurią galèjo sukurti per 1996 m. rinkimus daugiau kaip dvigubai (palyginti su 1992-aisiais) į Seimą patekusių moterų skaičius. Kaip pažymejjo tuometinė Lietuvos moterų partijos lyderẻ Kazimira Danutė Prunskienè, nepaisant ryškaus moterų pranašumo, palyginti su 1992-ųjų rinkimų rezultatais, „moterys vis dar negali vaidinti reikšmingo vaidmens sprendimu priemime" (Seimas, 1996). O 2000 m. Seime, moterų daliai sumažejus iki 11 proc., jau buvo galima ižzvelgti stipresnio feministinio sąmoningumo požymius: $2004 \mathrm{~m}$. atlikto tyrimo informantai minèjo socialinio atstovavimo principus ir „skaičiu sociologiją“. Socialliberalai ir socialdemokratai parlamentarai vyrai tvirtino, kad „remiantis Lietuvos statistika ir formaliaja logika, optimaliausiai būtų Seime turèti 48 proc. vyru ir 52 proc. moterų", tačiau kartu pabrèždavo, jog iš tiesų nèra nei galimybių, nei poreikio igyvendinti ši veidrodinị tikslų lyčių atstovavimą. Seimo narè socialdemokrate akcentavo, kad norint turèti įtakos Seime vykstantiems procesams, moterų šioje institucijoje turètų būti bent jau trečdalis.

Anot Lietuvos socialdemokratų partijos atstovo, 1996 m. Seimo rinkimų rezultatus lyčių atžvilgiu lemė trys svarbūs dalykai: pirma, profesionalių moterų politikių elgsenos modeliai - 80-ųjų pabaigoje ir 90-ųjų 
pradžioje Sąūūžio lyderès moterys (ypač K. D. Prunskienè, žinoma kaip Lietuvos gintarinè ledi, pirmoji Ministrè Pirmininkè posovietinèje Lietuvoje ir Moterų partijos iniciatorè); antra, šiek tiek pagal sovietinę ideologiją, tačiau su skirtingu politiniu atspalviu Lietuvos gyventojų puoselëjama demokratinio atstovavimo visoms socialinèms grupèms idëja; trečia, savita rinkimų kampanijos konjunktūra, sudariusi sąlygas naujai kadencijai perrinkti nemažai buvusių moterų parlamentarių.

Moters politikès vaidmens modelio svarbą pažymèjo ir kita tyrimo dalyvè. „1992 m. Seime buvo tik keletas moteru, bet jos visos buvo stiprios ir motyvuotos, nes jos visos atejo su Sajūdžiu ir pasiliko Seime po 1992 m. “, - teigè socialdemokratè (Seimas, 1996).

Daugelis parlamentarų vyrų, vertindami moterų politinio atstovavimo Seime pokyčius, kreipè dèmesị ne tiek ị moterų asmenybes, kiek $\mathfrak{i}$ politines partijas, pabrèždami politinių partijų panašumus per rinkimus ir neigdami būtent moterų sèkmę rinkimuose. „Rinkimus laimi partija. Aš nemanau, kad ji laimi todèl, kad jos sąraše yra moterų. Tikrai nemanau, kad tai partijos sèkmę rinkimuose lemęs dalykas <...> Lietuvoje tai vyksta savaime: tiesiog taip atsitiko, kad i partija atejo ryškios asmenybès, kurios savaime pagyvino partija. Kitais metais viskas gali pasikeisti, taigi ir partiju proporcijos parlamente keisis“, - kalbejo Lietuvos tautininku partijos atstovas (Seimas, 1996).

Kiti parlamentarai priešingai - akcentavo moterų asmeninių ir profesinių savybių svarbą. Anot socialdemokratès, „viskas priklauso nuo moters pasiruošimo, jos kompetencijos - kiek stipriai ji nori būti politikoje“ (Seimas, 2000). Kitas Seimo narys socialdemokratas menko moterų atstovavimo Seime priežastimi įvardijo pačias moteris (tiek politikes, tiek rinkejjas). Pabrèždamas, kad rinkimų metu moterys rinkejjos labiau linkusios balsuoti už vyrus, jis įžvelgè poreikị keistis tiek politikèms, tiek rinkejjoms. Savo ruožtu liberalas tvirtino, kad „mūsų moterys - Seimo narès - yra emancipuotos: jos nesigédija rūkyti viešumoje, įsitraukti i karštas diskusijas ar aršiai ginti savo pozicijos" (Seimas, 2000).

Visi apklaustieji parlamentarai sutiko, kad tiek vyrai, tiek mote- 
rys privalo dalyvauti visuose politikos formavimo lygmenyse, t. y. tiek tarptautiniame, tiek nacionaliniame, tiek vietos. Nors kai kurie 1999 m. atlikto tyrimo informantai pripažino Lietuvoje esant nepakankamą moterų atstovavimą nacionaliniu lygmeniu, $2004 \mathrm{~m}$. tyrimo dalyviai nesureikšmino 2000-aisiais sumažèjusio moterų skaičiaus Seime. Kaip teigè socialdemokratas: „Niekas politiku nediferencijuoja ị vyrus ir moteris; pripažinima gali laimèti abu, tiek vyrai, tiek moterys" (Seimas, 2000).

Kai kurie Lietuvos parlamentarai (tiek vyrai, tiek moterys) pareiškè, kad lytis neturi jokios ịtakos nei ịstatymų leidybai, nei Seimo organizacinei kultūrai, ir savo argumentus grinde tokiais teiginiais: „Valstybine politika labiausiai priklauso nuo ideju ir joje dalyvaujančiu asmenybiu“" (Tautininku partijos narys, Seimas, 2000) arba „Tiek vyrai, tiek moterys gali turèti tokius pat tikslus ir idèjas" (socialdemokratè, Seimas, 2000). Ir tik viena socialdemokratè su pesimistine gaida pripažino, kad didesnis moterų skaičius Lietuvos parlamente neatneštų svarbių pokyčių, nes „vadovaujančias pozicijas vis tiek užima vyrai“"(Seimas, 2000).

Dalis Seimo narių moterų dalyvavimo politikos formavime poreikį ir reikšmę grindè tradicinès patriarchalinès kultūros argumentais, pabrèžiančiais ypatingą moterų patirtị šeimoje ir ugdant vaikus. Moterų atstovavimas nacionaliniame politiniame elite yra svarbus, nes „netgi šeimoje viskas klostosi geriau, jeigu jos gerbūviu rūpinasi abu: vyras ir moteris“ (socialdemokrate, Seimas, 2000); be to, „yra sričiu, kuriose moterys yra labiau kompetentingos dèl turimos patirties šeimoje ir visuomeniniame gyvenime" (Naujosios demokratijos partijos narè, Seimas, 2000). Socialdemokrato vertinimu, prasminga vadovautis tradicine lyčių santvarkos versija, t. y. moterims ir vyrams atstovauti „skirtingiems pasauliams“. Jo žodžiais tariant, „nèra abejoniu, kad tiek vyrų, tiek moteru dalyvavimas Seime sąlygoja geresni visuomeniniu ir socialiniu santykiu atstovavima; tokiu būdu geriau atsispindi šeimos santykiai ir rūpinimasis vaikais" (Seimas, 2000).

Nors parlamentarai (tiek vyrai, tiek moterys) išreiškè tvirtus ịsitikinimus, kad didejjantis moterų skaičius Seime leistų pakeisti „politikos prio- 
ritetus ir vertybes“ (socialdemokratè, Seimas, 2000), ir „lyčiu pusiausvyra nuvestu prie geresniu sprendimu“ (socialdemokratas, Seimas, 2000), vis dèlto jų pasisakymuose išliko stiprus asmeninių savybių akcentavimas, pabrěžiant, kad „viskas priklauso nuo konkrečiu individu““. Pavyzdžiui, moterų dalyvavimas formuojant politiką teigiamai paveiktų įstatymų leidybos procesus tik su ta sąlyga, jeigu "tos moterys būtų protingos" (socialdemokratas, Seimas, 2000).

Kita grupè argumentų, pagrindžiančių moters politikès karjeros reikšmę, nukreipia ị vertybinius ir etinius moterų „kitoniškumo“ aspektus ir jų poveikị îstatymų leidybai. Kaip pažymėjo vienas socialdemokratas, „vyrai elgiasi mažiau apgalvotai ir linke ginčytis; tačiau jeigu aplinkoje yra moteru, mes (vyrai) nesiginčijame taip ịnirtingai kaip galètume" (Seimas, 2000). Taigi moteris politikè yra ne tik asmuo su skirtingomis vertybėmis ir nuostatomis; ji taip pat yra ir filosofų (postmodernistų) išskiriamas Kitas. Seimo narès taip pat pripažista savo, kaip moterų, „kitoniškumą“. Jos ịsitikinusios, kad ,jeigu politikoje būtų daugiau moteru, ji būtu labiau humaniška" (Lietuvos demokratinès darbo partijos narè, Seimas, 2000), „tai leistų konstruktyviau spręsti problemas ir priimti sprendimus, pagristus konsensusu“" (konservatorè, Seimas, 2000).

Tai, kad lytis veikia organizacinius ịstatymų leidybos aspektus, pripažino abiejų lyčių parlamentarai. Ne tik moterys minèjo, bet ir patys vyrai pripažino kartais turintys išankstinių nuostatų moterų atžvilgiu. „Kai kuriems ịstatymu projektams Seime būtų labiau pritarta, jeigu juos pristatytu vyrai; kartais moterys nežino, kaip reikia pristatyti klausimus, kartais mes (vyrai) turime išankstinę nuostatą, kodèl turime klausyti moters", sakè liberalas (Seimas, 2000). Demokratinès darbo partijos narè tvirtino, kad „kartais Seime sakoma, „suteikime žodị moteriai“ - tarsi yra labai svarbu, kas kalba - vyras ar moteris. Taip išreiškiamas užslèptas nusistatymas, kad „ko gi mes galime tikètis iš vargšès moters?", kuris yra lydimas mintimis, „ai, galime tai praleisti, juk tai kalba moteris..." (Seimas, 2000).

Kai kurios parlamentarès ne tik pripažįsta savo „kitoniškąa" veikimą formuojant politiką, bet ir mielai puoselèja savo „kitoniškumą“, pabrèž- 
damos, kad „nors vyrams politikoje yra leidžiama daugiau, jos kaip moterys privalo išsaugoti savo moteriškuma" (konservatorè, Seimas, 2000). Vienas informantas taip paaiškino šią „moteriškumo“ strategiją: „Moterys, kurios naudojasi savo moteriškumu, daugiau pasiekia savo karjeroje negu tos, kurios to nedaro. <...> Manau, tai taip pat yra politine veikla, ir jeigu moteris nori eiti pirmyn, ji turi visiems šypsotis, su visais kalbètis ir büti meili. <...> tokia moteris yra sèkmingesnè nei, tarkime, ta, kuri ateina ir tiesmukiškai rěžia savo tiesas. Netgi jeigu jos „tiesa“ skamba labai dažnai, jai sunku yra susilaukti palaikymo" (socialdemokratas, Seimas, 2000). Taigi „tikroji moteris“, kuri naudojasi savo „moteriškumu“, turi daugiau galimybių laimèti politiniuose ginčuose. Kitokia (nemoteriška?) parlamentarè priskiriama „pralaimètojų“ kategorijai, o jos bandymai aktyviai veikti formuojant politiką laikomi desperatiškais žaidimais.

Apibendrinant svarbu pabrèžti, kad nepaisant dominuojančių akivaizdžiai patriarchalinių nuostatų moterų Seime ir jų elgesio atžvilgiu, moterų atstovavimo parlamente klausimas nèra laikomas svarbia visuomenine problema. Apskritai, daugumos parlamentarų akimis, moterų dalyvavimas įstatymų leidžiamojoje valdžioje Lietuvoje nèra suvokiamas kaip problematiškas, nors visos moterys parlamentarès, išryškindamos skirtingus niuansus, mano, kad moterų klausimai yra politiniai.

\section{Variacijos lyčių kvotų diskurse: individualus, politinès partijos ir kadencijos veiksniai}

Kaip rodo vyrų ir moterų parlamentarų interviu, lietuvių kolektyviniuose vaizdiniuose yra įsitvirtinusios keletas stiprių politikių moterų. Tačiau interviu duomenys ir Lietuvos politinio gyvenimo realijos rodo, kad šalies politikai nepalaiko lyčių kvotų ịvedimo nacionaliniu lygmeniu. Interviu su politiniu elitu analizė atskleidè, kad tik dalis informantų, vertindami lyčių kvotų ịtvirtinimo galimybes, problemų ižzvelgẻ ne kvotose. Pagrindiniai argumentai išryškino poreikị partijų gretose turèti gerus ir konkurencingus specialistus: kai „moterys, ateinančios i politines parti- 
jas, bus pasirengusios konkuruoti: profesionaliai dirbti juairiose srityse, parodant savo veiklos rezultatus, $<\ldots>$ mes turésime pakankamai moteru ir be kvotu sistemos" (Centro sajungos narè, Seimas, 1996). Kitos 1996 m. išrinktos parlamentarès tokiam pareiškimui suteike šiek tiek kitoki kontekstą. Pavyzdžiui, konservatorių atstovè pabrèžè, kad „vyrai mūsu partijoje, sudarydami rinkiminius sąrašus, net negalvoja apie tai, kad ị juos neįtrauktu moteru“. Taigi informantè aiškiai nurodè, kad būtent vyrai jų partijoje turi galią (ir teisę) sudaryti rinkimų sąrašus ir (dèl turimos galios) spręsti apie moterų kompetenciją kandidatuoti rinkimuose. Kita konservatorè buvo dar atviresnè, pasakodama, kaip jos partijos kolegos vyrai sako: „Pasakykite mums, kokiu kvotu jums reikia ir mes jas suteiksime. Tik suraskite šias protingas moteris“ (konservatorè, Seimas, 1996).

Nors tuometinio Seimo moterys aiškiai nurodè jaučiančios savo partijos kolegų vyrų paramą ir palaikymą, apibūdindamos šios paramos kontekstą, dèmesị nukreipè nuo moterų prie vyrų ir, galbūt pačios to neįsisąmonindamos, nurodè, kad partijoje vyrauja tradicinẻ lyčių tvarka, kai būtent vyrai priima pagrindinius spendimus ir ịtraukia (arba ne) moteris ị rinkimų sąrašą arba suteikia kvotas.

Lyčių kvotų ịtvirtinimas pokomunistiniu laikotarpiu gali būti siejamas su siekiu prilygti kitoms ES demokratinių valstybių partijoms, jas kopijuojant ${ }^{49}$. Tačiau Lietuvos duomenys nesuteikia jokių aiškių ir ryškių tokios institucinès imitacijos požymių. Interviu metu tik kai kurie Lietuvos parlamentarai užsiminè apie tiesioginị ryšį tarp lyčių kvotų ittvirtinimo ir Vakarų (būtent Skandinavijos) šalių patirties. Ypač šios sąsajos išryškejjo Lietuvos socialdemokratų partijos atstovès pasakojime: „Mūsų ryšiai su politinemis partijomis Skandinavijoje yra labai artimi. Lietuvos socialdemokratu požiūriai i moterų klausimus yra paveikti Skandinavijos šalyse veikiančiu socialdemokratų moterų. Tai, kad Švedijos, Danijos, Suomijos ir Islandijos parlamentuose moterys sudaro 40 proc. ar 50 proc. ïro-

${ }^{49}$ Matland, R.E. The Representation of Women in Political Parties in Central and Eastern Europe. The Political Representation of Social Interests in Central and Eastern Europe: Workshop Section 2. 2004, p. 15. 
do, kad iš šiu šaliu yra ko pasimokyti. Ir tai taip pat padeda mums ịtikinti mūsu vyrus, kad lyties klausimai yra svarbūs" (Lietuvos socialdemokratų partijos narè, Seimas, 1996). O viena konservatorè su tam tikru skepticizmu užsiminė, kad „šios kvotos yra perimtos iš Skandinavijos socialdemokratiniu partijų“.

1996 m. išrinktų Seimo narių pasakojimuose nuorodos ị Skandinavijos lyčių politiką buvo ne tik dažnesnès nei $2004 \mathrm{~m}$. informantų atsakymuose, bet ir skyrèsi savo turiniu. Pirmojo tyrimo metu parlamentarai labiau akcentavo $1998 \mathrm{~m}$. Lietuvoje priimto Moterų ir vyrų lygių galimybių įstatymo „skandinaviškajji pamatą“. 2000 m. išrinkto Seimo nariai, dalyvavę apklausoje, rečiau minèjo Skandinavijos šalis, bet labiau siejo jas su tuo, „kaip lyčių lygybès principus paversti tikruoju sprendimų prièmimu“. Vienas Seimo narys socialdemokratas, bandydamas paaiškinti lyčiu kvotų poreiki demokratinejje politikoje ir vèlgi, nurodydamas lyčių skirtumus, pasiūle prisiminti Skandinavijos pavyzdį: „Abejoju, kad moterys turés tokius pat prioritetus užsienio politikoje, arba kad jos teiks prioriteta ekonomikai. Tradiciniam vyrui svarbiausia yra ekonomika, tuo tarpu socialiniai klausimai eina iš paskos. Man asmeniškai ekonomika nèra aukščiau už socialinius reikalus, manau, jie turi eiti lygiagrečiai... Pažiūrejus i Skandinavijos parlamentus, kuriuose moterys sudaro 40 proc. ir daugiau, aiškiai matyti dideli skirtumai biudžeto sandaroje" (socialdemokratas, Seimas, 2000). Taigi, socialdemokratai pripažǐsta, kad didesnis moterų, dalyvaujančių formuojant politiką, skaičius sudaro palankesnes sąlygas socialiai sąmoningai ir rūpestingai planuoti biudžetą. Savo ruožtu liberalas išreiške gana kritišką Skandinavijos praktikos taikymo Lietuvoje vertinimą, baimindamasis, kad „mechaniškas perkèlimas $j$ mūsu aplinka to, kas natūraliai savaime susiformavo Skandinavijoje per ilga laika, gali sukelti atmetimo efekta" (liberalas, Seimas, 2000).

Galima išskirti dvi lyčių kvotų diskurso kryptis - feministinę ir neutraliaja. Pavyzdžiui, socialdemokratas sakè: „Mes turime labai aiškia formulę: sąraše turi būti ne mažiau kaip 1/3 kitos lyties atstovų. Taigi mažumoje gali būti ir vyrai" (Seimas, 1996). Kiti parlamentarai laikosi 
akivaizdesnès feministinès krypties. Lietuvos moterų partijos lyderẻ socialdemokratų partijoje taikomas lyčių kvotas vertina tik kaip dekoracijas ir simbolini gestą: „Tiesa yra tai, kad jų kvotos leido patekti i Seima tik trims moterims iš keturiolikos socialdemokratų. Ar tai panašu i sažzininga atstovavimą? Ar tai tikroji kvotu pasekmè? Aš manau, kad tai yra labiau simbolines kvotos. Kvotos parodo, kad, deja, socialdemokratai nori turèti tik keleta moteru“ (Seimas, 1996). Pripažistama: „Norint, kad lyčių kvotos iš tiesu veiktu ir galètu padidinti moteru skaičių daugiapartineje sistemoje, jos turi būti ịvestos sistemiškai daugumoje parlamentinių partijų“.

Idomu pastebeti, kad tyrimo metu pasitvirtino neigiamas sovietinès kvotų patirties poveikis vertinant pokomunistinių lyčių kvotų îtvirtinimą. Kaip teigè socialdemokratè, „Lietuvoje sovietmečiu veikusios kvotu. sistemos patirtis šiandien sukelia atmetima ir prieštaravimą. Todel kvotu sistemos pokomunistiniu laikotarpiu būtina atsisakyti“ (Seimas, 1996). Panašių nuostatų įžvelgiama ir liberalo reakcijoje ị klausimą apie kvotas: „Čia smarkiai kvepia bolševizmu“. Toliau pokalbyje jis akcentavo: „Kartoju: lyčiu kvotos yra atejusios iš socializmo. Šiandien jos yra perkeliamos iš Vakaru Europos. Man socializmas - bet kokioje jo formoje - nèra priimtinas. Nesvarbu, ar tai bus švediškas, ar rusiškas. Aš esu liberalas, juo ir liksiu“(Seimas, 1996).

Tautininkų diskurse neigiamas sovietinių kvotų vertinimas yra dar akivaizdesnis. Tautininkų partijos atstovas nepritarė bet kokių išskirtinių sąlygų sudarymui, nes „tai primena sovietmeti, kuomet tarp deputaty buvo atitinkamas skaičius ükininkų, darbininkų ir jaunimo... Ař negaliu tam pritarti. Manau, kad lyčiu kvotu sistemos įtvirtinimas legalizuotu lyčių nelygybę" (Seimas, 1996).

Svarbu pažymèti, kad lyčių kvotų itvirtinimo galimybių sovietinio palikimo kontekste vertinimai yra stipriai susiję su informantų ideologine pasaulěžiūra. „Iš esmès aš vertinu ir palaikau pagalbq spręsti moteru problemas. Tačiau esu prieš bet kokį šių klausimų ideologizavimą ir norą apsaugoti liberaliają ideologija“" - tvirtino 1996 m. išrinkto Seimo narys liberalas.

Dalis argumentų, susijusių su Seimo narių priešinimusi lyčių kvo- 
toms, buvo grindžiami nuostata, kad kvotos peržengia bendruosius demokratijos principus. Pavyzdžiui, socialdemokratas teigè, kad „specialiosios priemonès yra nereikalingos; joms priešinamasi ne dèl lyties, bet dèl to, kad demokratijoje kiekvienas turi būti ịtrauktas i politinius procesus $<\ldots>$ Žmonés nèra kvaili ir balsuos už kiekviena, kuris bus protingas - nesvarbu, ar tai bus vyras, ar moteris" (Seimas, 2000). Seimo narių nuomone, menkas moterų atstovavimas Lietuvos parlamente yra laikomas natūraliu demokratinio žaidimo rezultatu, o priemonès, skirtos padidinti moterų atstovavimą, laikomos antidemokratinèmis.

Tačiau nepakankamo moterų ịsitraukimo ị politikos formavimą struktūrinès priežastys nuolatos buvo paremiamos antriniais argumentais. 2000 m. išrinkto Seimo narè konservatorè savo neigiamą kvotų politikoje taikymo vertinimą grindè nuostata, kad „politikoje turi varžytis asmenybès, o ne lytis“, taigi „rinkiminès kvotos yra dirbti$n e ̀ s$, diskriminuojančios viena lyti“. Be to, „kvotos neatitinka visuomeniniu lūkesčiu“. „Tokie dalykai, kaip lyčiu lygybè, turi plètotis savaime ir turi būti priimti politiku, bet neprimesti formaliosios teisès", - tvirtino liberalas (Seimas, 2000).

Kai kurie neigiami lyčių kvotų ịtvirtinimo galimybių vertinimai buvo grindžiami argumentais, akcentuojančiais moteris žeminantị ir menkinantị kvotų poveikį. Pavyzdžiui, 1996 m. išrinkto Seimo narys liberalas, svarstydamas galimus lyčių kvotų ívedimo rezultatus, teigè, kad „kvotos sudarys daugiau galimybių žemos kvalifikacijos žmonèms“. Manoma, kad nesant varžovų, šie žemos kvalifikacijos atstovai būtinai būtų moterys. Tos pačios partijos moteris, pristatydama labiau partijos, nei asmenines nuostatas lyčių kvotų atžvilgiu, pažymėjo, kad „mes diskutavome apie lyčiu kvotas dar 1995, prieš pat rinkimus. Bendroji nuomone buvo, kad bet kokiu kvotu ìvedimas diskredituotu moteris <...> tuomet jūs žinotumète, kad esate aukštose pozicijose, nes esate moteris, o ne todel, kad gerai dirbate savo darba arba esate geresné" (Seimas, 1996).

Idomu, kad rūpinimasis moterų vidine savijauta, kuriai lyčių kvotos tik pakenktų, dažniau skambejjo vyrų politikų vertinimuose. 
2000 m. išrinkto Seimo narys liberalas tvirtino, kad „lyčiu kvotos išreiškia nepagarba moterims, nes tokiu atveju moterys yra vertinamos kaip antrarūšès proceso dalyvès, tarsi jos pačios neturi pakankamai gebejjimy ir galios atsidurti partijos rinkiminiuose sąraše“. Panašūs vertinimai įžvelgiami ir Tautininkų partijos atstovo žodžiuose: „Lyčių kvotos žemina moteris; jos tarsi parodo, kad vyras ir moteris néra lygūs Dievo akivaizdoje. Gerai, gal tuomet taikykime specialiasias priemones garbanotiems, plikiems žmonèms, siauraakiams, aukštiems ir žemaūgiams <...> abu (vyrai ir moterys) yra Dievo kūriniai. Manau, kad lyčiu kvotos yra beprasmiškos" (Seimas, 2000).

Vis dèlto parlamentarai įžvelgè ir palankių aplinkybių lyčių kvotų, kaip laikinosios priemonès, ịvedimui. Teigiamą požiūrị šiuo klausimu išreiškè nors vienas vyras: „Aš galiu toleruoti kvotas kaip laikina priemone <...> jeigu reikia laikinai sustiprinti kai kuriuos atstovavimo aspektus <...> noréčiau, kad ilgainiui kvotos išnyktų. Viskas, kas susiję su lyčiu lygybès įtvirtinimu, turi büti reguliuojama ir skatinama" (Seimas, 1996).

Taigi lyčių kvotų, kaip moteris žeminančios priemonès, diskursas buvo plètojamas tiek 1996, tiek 2000 m. Seimuose. Tačiau 2000 m. ryškus moterų Seime skaičiaus nuosmukis lèmė tai, kad pasipriešinimas lyčių kvotų ịvedimui nyko iš Seimo moterų pasakojimų. „Aš balsuočiau už lyčių kvotų rinkiminiuose sąrašuose j̣vedima, nors ir nemanau, kad kvotos kaip priemonès yra geros pačios savaime <...> moteru atstovavimas turètu büti politine problema, nors ji tokia ir néra. Todel reikalingos tikros specialiosios priemonès" (Demokratinès darbo partijos narè, Seimas, 2000). „Taip, aš palaikyčiau pastangas ịtvirtinti lyčiu kvotas. Jeigu mes neịtvirtinsime kvotu, vyrai ir toliau kels save $i$ pirmaujančias pozicijas rinkiminiuose sąrašuose $<\ldots>$ todèl būtina paskatinti moteris, tiesiog joms šiek tiek labiau praveriant duris. Moterys tikrai eitu i politika, nes jos to nori. Jos tik turi būti padrasintos, joms reikia pagalbos suprasti save, suteikti didesnio pasitikejimo savimi“ (Liberalų ir centro sąjungos naré, Seimas, 2000). 
Beveik visos 2000 m. išrinktos Seimo moterys (išskyrus dvi konservatores) palaikè lyčių kvotų taikymą sudarant rinkimų sąrašus. Tačiau iš tyrime dalyvavusių 14 vyrų parlamentarų tik du pritarè tokioms priemonėms. Tai, kad nè vienas iš keturių apklausoje dalyvavusių socialdemokratų partijos, kurioje taikomos lyčių kvotos, vyrų teigiamai neįvertino lyčių kvotų ịtvirtinimo idejjos, leidžia daryti prielaidą apie šios partijos viduje egzistuojančią vyrų opoziciją dèl lyčių kvotų.

Tyrimo rezultatai gali būti analizuojami panaudojant intersekcionalumo sąvoką, akcentuojančią „ryšius tarp tradicinių lyties, etniškumo, rasès, amžiaus, seksualumo ir klasès kategorijų “50. Remiantis atliktų tyrimų duomenimis, siūloma išplèsti intersekcionalumo sąvoką, išvardytų individualių socialinių charakteristikų sąrašą papildant asmens priklausomybès politinei partijai kategorija.

Priklausomybè politinei partijai lemia ir moterų dalyvavimo politikos formavimo procese galimybes. Atsižvelgiant ì praktinị konkrečių situacijų diskursą (pvz., lyčių kvotų taikymo rinkimų sąrašuose interpretacijas) pastebèta, kad tik Lietuvos socialdemokratų partijos moterys turi institucinę galimybę būti paskatintos ir dèl lyčių kvotų atsidurti partijos rinkimų sąrašuose. Tačiau tai nereiškia, kad moterų socialdemokračių politinis dalyvavimas turètų būti mažiau intensyvus nei kitų partijų moterų. Konservatorių moterų atvejai parodè, kad moterys yra labiau linkusios palaikyti partijos poziciją (neigiamai vertinti specialiąsias priemones, skirtas didinti moterų atstovavimą). Todèl būdamos priešiškos lyčių kvotų atžvilgiu, konservatorès moterys (kaip ir vyrai) apriboja moterų galimybes prisidèti prie politikos formavimo. Taigi, galima tvirtinti, kad ne tik menamas moteru „kitoniškumas“ tarp parlamentarų, bet ir jų priklausomybė tam tikrai politinei (šiuo atveju - konservatorių) partijai yra politiškai moterims nepalankios situacijos šaltinis.

${ }^{50}$ Staunaes, D. Where have all the subjects gone? Bringing together the concepts of intersectionality and subjectification. NORA Nordic Journal of Feminist and Gender Research. 2003, vol. 2, p. 101-110. 


\section{Išvados}

Politikos teorija ir empirinių studijų rezultatai rodo, kad moterų atstovavimas naujosiose demokratijose apima tiek specifini pokomunistinị struktūrinị (susijusị su daugiapartinès partijų sistemos plètra), tiek diskursyvinị (susijusị su viešosios erdvès liberalizavimu) kontekstus. Atliekant analizę buvo atsižvelgiama ị lyčių kvotų pobūdị ir jo santykị su valstybių istoriniu palikimu, sociokultūrinèmis tradicijomis. Gauti duomenys parodè, kad lyčių kvotų taikymas politikoje skiriasi pavienėse pokomunistinèse ir senosiose Europos valstybėse. Šiuo atveju Lietuva priskiriama tarp Vakarų valstybių grupès su senomis moterų politinio dalyvavimo tradicijomis ir naujųų pokomunistinių demokratijų, kuriose moterų politinė socializacija vyko taikant sovietines politines praktikas.

Lietuvos moterų atstovavimo parlamente diskurso analizè, ypatingą dèmesį skiriant lyčių kvotų institucionalizavimui, patvirtino ankstesnių JAV ir Europoje atliktų tyrimų rezultatus, kad diskurso turinys ir pasipriešinimo tokioms priemonėms intensyvumas kinta priklausomai nuo demokratinès tradicijos šalyje tęstinumo ir nuo moterų skaičiaus esamame parlamente: kuo daugiau laiko praeina nuo demokratijos kūrimo pradžios, tuo mažiau moterų atstovavimą palaikančios priemonès asocijuojamos su sovietine patirtimi; kuo mažiau moterų politikių yra Seime, tuo stipresnis jų palaikymas minimoms moterų atstovavimą skatinančioms institucinèms priemonėms.

Pirmiausia buvo nustatyta, kad 1996-2000 m. kadencijos Seime išliko stiprus lyčių kvotų, kaip sovietinio palikimo, diskursas, pagrindžiantis pasipriešinimą lyčių kvotų įtvirtinimui ankstyvųjų pokomunistinių reformų metu. Laikui bėgant nepalankus diskursas keitėsi ir 2000-2004 m. kadencijos Seime, kurio išrinkti nariai buvo nedaug jaunesni už ankstesnès kadencijos parlamentarus (atitinkamai amžiaus vidurkis $m=48$ ir $\mathrm{m}=49$ ), vadinasi, jie irgi socializavosi dar sovietmečiu, neigiamas lyčių kvotų siejimas su sovietine praeitimi pastebimai nunyko. Tikriausiai viena šios lyčių diskurso variacijos priežasčių yra aktyvaus Lietuvos pa- 
siruošimo stojimui ị ES laikotarpis, t. y. Lietuvai siekiant tapti ES nare, palankus lyčių klausimų įtraukimas ị politinę darbotvarkę virto įsisąmoninta būtinybe.

Nustatyta, kad moterys parlamentarès palankiau nei vyrai vertina specialiąsias priemones, skirtas didinti moterų politinị dalyvavimą ir atstovavimą. Jeigu 1996 m. išrinktame Seime lyčių kvotų iniciatyvos labiausiai buvo skatinamos Moterų partijos atstovių ir pavienių Seimo narių ir iš esmès nebuvo suvokiamos kaip problema, tai po $2000 \mathrm{~m}$. rinkimų tarp Seimo narių moterų palankumas lyčių kvotoms išaugo. Šią diskurso variaciją didžiąja dalimi lèmè stiprus moterų skaičiaus Seime sumažèjimas po 2000 m. rinkimų. Beje, Seimo parlamentarai vyrai, siekdami pateisinti sumažejjusį moterų atstovavimą ir išvengti diskusijos lyčių kvotų tematika, dažnai naudojo „aukos kaltinimo“ strategiją: Seimo ir partijų narès bei moterys rinkejjos buvo kaltinamos nesolidarumu, neprofesionalumu, kompetencijos stoka ir pan.

Akcentuotina, kad parlamentarų požiūris ị lyčių kvotas yra sąlygotas priklausomybės politinei partijai: Lietuvos konservatoriai vieningai (tiek vyrai, tiek moterys) kritikavo lyčių kvotų idejją, o socialdemokratai pozityviau nei kitų partijų nariai vertino lyčių kvotas. Vis dèlto nè vienas socialdemokratas vyras nelaikẻ lyčių kvotos būtina teisèta priemone.

Taigi, pagrindiniu diskurso variacijas paaiškinančiu kintamuoju išlieka pati lytis. Beveik visi parlamentarai vyrai deklaravo priešiškas nuostatas bet kokių specialiųjų priemonių, skirtų sustiprinti moterų politinị atstovavimą, atžvilgiu. Seimo narių vyrų priešiškumas lyčių kvotoms dar labiau sustiprejo bėgant laikui ir Seimo narèms pradejjus demonstruoti savo feministinị sąmoningumą. Taigi, nors lyčių lygybės idejja Lietuvos politikoje igauna vis didesnị pagreitị, pasipriešinimas jam irgi auga. Per pastaruosius dvidešimt metų Lietuvos politinè sistema išgyveno milžiniškus pokyčius, tačiau, netgi tautai išrinkus prezidentę moterị, moterų atstovavimas aukščiausiuose politiniuose lygmenyse išlieka paviršutinis, o viešajame diskurse ir toliau pristatomas kaip nereikšmingas politinis klausimas. 


\title{
EXPANDING OPPORTUNITIES FOR POLITICAL REPRESENTATION? ANALYSIS OF LITHUANIAN PARLIAMENTARIANS’ VIEWS ON GENDER QUOTAS
}

\author{
Irmina Matonyté, OKsana Mejeré
}

\section{Summary}

Keywords: political representation; gender quota; parliamentary elite; women.

Political theory and empirical research demonstrates that women's political representation involves special post-communist structural (related to multi-party system development) and discursive (related to liberalization of the public sphere) contexts of new democracies. With the interview data from post-communist Lithuanian political elite, we confront experience of formal structural gender representation during the Soviet regime and observe deteriorating women's parliamentary representation in the early democratic politics. Cognitive, emotional and normative stances of MPs (men and women) towards the issue of gender quotas provide useful tools to look deeper into the re-organization of the very principles and concept of political representation in new democracies. Based on materials of semi-structured interviews with Lithuanian parliamentarians (parliamentary term 1996-2000, $\mathrm{n}=11$; and parliamentary term 2000-2004, $\mathrm{n}=28$ ) we analyze variations of discourse concerning women's political representation in general and establishment of gender quotas in particular. Our analysis reveals that neither political party affiliation, nor "contagion" effects, nor economic and social development related factors increase individual support for gender quotas and women's representation in the parliamentary arena; the explanatory variable is the gender itself: most women MPs would support special measures (including quotas) for enhancement of women, but not men MPs. Furthermore, content of discourses and discursive resistance (against quotas) varies across the length of democratic experience and depends on the share of women MPs in the actual parliament: the fewer women parliamentarians, the stronger is their support for quotas; the later the period, the less are quotas associated with the despised soviet heritage. In addition, to reveal women's quotas parliamentary situation-bounded supportive discourse, but not growing feminist consciousness in general, we also suggest some implications related to intersection of gender and political party affiliation. 